\title{
Projet de désendettement : La Suisse et l'endettement des pays pauvres
}

Projekt Entschuldung : Die Schweiz und die Verschuldung der ärmeren

Entwicklungsländer

Tobias Bauer

\section{CpenEdition}

\section{Journals}

Édition électronique

URL : http://journals.openedition.org/aspd/1360

DOI : 10.4000/aspd.1360

ISSN : 1663-9669

Éditeur

Institut de hautes études internationales et du développement

Édition imprimée

Date de publication : 1 janvier 1988

Pagination : 223-238

ISSN : 1660-5934

Référence électronique

Tobias Bauer, « Projet de désendettement : La Suisse et l'endettement des pays pauvres », Annuaire suisse de politique de développement [En ligne], 7 | 1988, mis en ligne le 05 avril 2013, consulté le 08 septembre 2020. URL : http://journals.openedition.org/aspd/1360 ; DOI : https://doi.org/10.4000/ aspd. 1360

Ce document a été généré automatiquement le 8 septembre 2020

(c) The Graduate Institute / Geneva 


\title{
Projet de désendettement : La Suisse et l'endettement des pays pauvres
}

\author{
Projekt Entschuldung : Die Schweiz und die Verschuldung der ärmeren \\ Entwicklungsländer
}

Tobias Bauer

\section{NOTE DE L'ÉDITEUR}

En français, résumé seulement. Lire l'article original en allemand dans Schweizerisches Jahrbuch für Entwicklungspolitik : « Projekt Entschuldung: Die Schweiz und die Verschuldung der ärmeren Entwicklungsländer ", http://sjep.revues.org/1180.

\section{RÉSUMÉS}

L'auteur décrit un projet d'allégement de la dette du tiers-monde, qui a été lancé en 1986 par une initiative conjointe de deux œuvres d'entraide des églises (Pain pour le Prochain et Action de Carême), de l'Institut d'éthique sociale de la Fédération des Eglises protestantes de la Suisse et de la Commission nationale Justifia et Pax.

L'objectif de ce programme d'études et d'action, dont les activités s'étendront sur plusieurs années, est d'élaborer des propositions de mesures que la Suisse pourra prendre en faveur du désendettement du tiers-monde. Ces propositions seront soumises à une discussion publique. Le projet se limite volontairement aux petits pays pauvres dont la dette en montant absolu est assez modeste. Tenant compte du poids relatif de la Suisse sur la scène internationale et de ses possibilités de contribuer à des solutions concrètes, il envisage la collaboration avec d'autres 
mini-états et avec les pays européens. A l'occasion du $700^{\text {ème }}$ anniversaire de la Confédération en 1991. une contribution particulière de la Suisse est envisagée en faveur de l'allégement de la dette du tiers-monde.

Dans une première partie, l'auteur examine l'importance, la structure et les perspectives de l'endettement des pays pauvres; dans la partie suivante, il analyse le poids de la Suisse sur le plan financier et économique mondial. Dans une troisième partie, les causes de l'endettement et la politique actuelle des créanciers sont exposés. Les grandes lignes du projet de désendettement sont présentées dans ta dernière section. 